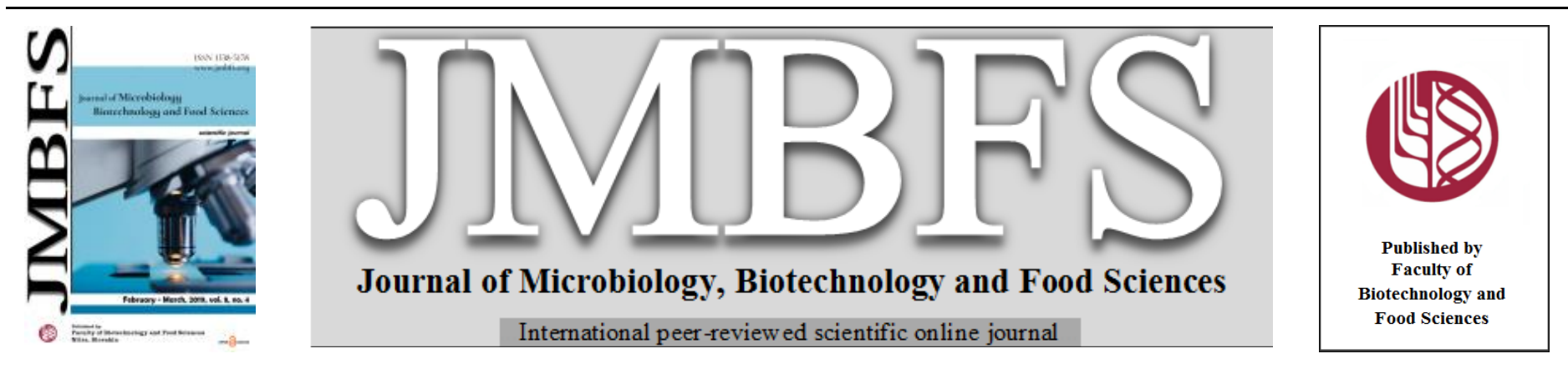

\title{
SENSORY EVALUATION OF FISHERY PRODUCT - COD IN MAYONNAISE
}

\section{Jana Tkáčovál, Adriana Pavelkovál, Alena Sajdovál, Mária Angelovičová ${ }^{2}$}

Address(es): Ing. Jana Tkáčová, PhD.

${ }^{1}$ Slovak University of Agriculture, Faculty of Biotechnology and Food Sciences, Department of Evaluation and Processing of Animal Products, 949 76, Nitra, Tr. A. Hlinku 2, Slovakia, +421376414348 .

${ }^{2}$ Slovak University of Agriculture, Faculty of Biotechnology and Food Sciences, Department of Food Hygiene and Safety, 949 76, Nitra, Tr. A. Hlinku 2, Slovakia, +421376415805 .

*Corresponding author: xtkacova@uniag.sk

doi: 10.15414/jmbfs.2019.8.4.1084-1088

ARTICLE INFO

Received 10.7. 2018

Revised 29.11. 2018

Accepted 29. 11. 2018

Published 1. 2. 2019

Regular article

OPEN $\partial_{\text {ACCESS }}$

\section{ABSTRACT}

The aim of this work was to compare the quality of selected fish product samples (cod in mayonnaise) of Slovak and Czech producers at the beginning and end of durability by sensory analysis. The products were approximately the same expiration date and were stored in a refrigerator. The samples were evaluated by a 5 point evaluation system with trained evaluators. The following descriptors have been assessed: general appearance, color, smell, harmonicity taste, palatability of the product, balance of fish-mayonnaise taste, salted, acidity, bitterness and possible foreign flavor. The results of evaluation were that product exhibits characteristic sensory properties during its use. The approaching ending of the durability date is the gradual overlapping of fish taste, such as an acetic taste, as reflected assessors' evaluation. Assessors put emphasis on balance of taste.

Keywords: fishery product, sensory evaluation, cod in mayonnaise, salad, durability

\section{INTRODUCTION}

Meat is defined by the American Meat Science Association as: "Skeletal muscle and its associated tissues (including nerves, connective tissues, blood vessels, skin, fat, and bones) and edible offal derived from mammals, avian, and aquatic species deemed as safe and suitable for human consumption. Terrestrial and aquatic species intended for human consumption, are also included" (Bohrer, 2017).

Meat is an important source of nutrients for most people wanting to consume a balanced diet. It is high in protein with a good balance of amino acids and high in several minerals and vitamins, which play important roles in metabolism and are more easily assimilated from meat than from other foods (Wood, 2017), it provides high quality proteins and other nutrients, such as vitamin B12 and iron (Beardsworth and Keil, 1997; Boland et al., 2013; Bekker et al., 2017) and meat is one of the most valuable sources of proteins, and also contains fats, B vitamin complex, vitamins $\mathrm{A}$ and $\mathrm{D}$, large amounts of iron, zinc, and other mineral substances (Baltic and Boskovic, 2015).

The nutritional composition of fats in fish and seafood are considerably different (contains less saturated fats) than in red meat and poultry, and from a health perspective may offer added benefits for consumers wishing to limit or monitor their intake of saturated fats, but may also not contain the same abundance of nutrients found in red meats; such as, iron and zinc (Ackman, 1988; Kaushik $\boldsymbol{e t}$ al., 2009; Mozaffarian, 2005; Bohrer, 2017).

Fish plays an important role in fighting hunger and malnutrition. Fish is not only a source of proteins and healthy fats, but also a unique source of essential nutrients, including long-chain omega- 3 fatty acids, iodine, vitamin D, and calcium. The multiple benefits of fatty fish high in omega-3s and small fish eaten whole containing nutrients in the skin and bones clearly illustrate seafood's irreplaceable nutritional value (FAO, 2018)

Polyunsaturated fatty acids (PUFA) have been a topic of scientific interest worldwide for decades. Strong and consistent evidence demonstrated the cardioprotective and antihypercholesterolemic effects of PUFA (Mensink $\boldsymbol{e t}$ al., 2003; Willett, 2012). Intake of omega-3 PUFA, especially marine longchain omega-3 PUFA (eicosapentaenoic acid (EPA) and docosahexaenoic acid (DHA)), has been linked with decreased risk of major chronic diseases, including cardiovascular disease (CVD), diabetes and Alzheimer's disease. However, evidence linking omega-3 PUFA intake to mortality still remains inconsistent (Mozaffarian and Wu, 2011; Simopoulos, 1999; Wallin et al., 2012; Zhang et al., 2016).
The report from the World Cancer Foundation/American Society of Cancer Research (World Cancer Research Fund) published in 1997 noted that there was insufficient evidence of decreased risk for breast and ovary cancer with increasing fish consumption. There was possible evidence of no relationship for colon and rectum cancer. In the same report, data on the relationship between cancer and the essential omega- 3 fatty acids from fish were considered insufficient. Similarly, a review articles published later found no evidence of any effect of the essential fatty acids (De Deckere, 1999; Lund, 2018).

Several scientific studies have confirmed positive effects of regular fish and other seafood consumption on human health, including (Mozaffarian and Rimm, 2006, Sioen et al., 2007, Pieniank et al., 2010, Morales and Higuchi, 2018) The main benefits of fish intake reported, apart from being a source of protein, are a reduction in the risk of sudden cardiac death (Albert $\boldsymbol{e t}$ al., 1998), a decrease in the incidence of cardiovascular disease (KrisEtherton et al., 2002) and high blood pressure and fish intake seems to provide antiarrhythmic protection at a population level (Chrysohoou et al., 2007), decrease in the incidence of depressive symptoms (Tanskanen et al., 2001) and Alzheimer's disease (Morris et al., 2003, Morales and Higuchi, 2018). The benefits of fish intake exceed the potential risks among adults (Mozaffarian and Rimm, 2006). Preservation regulates food so that it does not quickly succumb to decomposition process and it was possible to keep the raw material longer than allowed for its natural durability. The preservation method depends on the properties of the preserved product, availability sources, energy, storage options, used packaging material (Berkel, et al., 2004).

Marinades are ready to eat fish products consisting of fresh, frozen or salted fish or portions of fish processed by treatment with edible acids and salt and put up in brines, sauces, creams or oil (Topuz, 2016). Marination is a method of food preparation for many years. The term "marinades" or "marinated fish" is used to define fish products which consist of fresh, frozen or salted fish or portions of fish processed by treatment with an edible organic acid, usually acetic acid, and salt and put into brines, sauces or oil (Meyer 1965). Marinades are semipreservatives; acid and salt are added to the fish to retard the growth of bacteria and inhibit enzyme activities, resulting in a product with a characteristic flavor and an extended, but restricted shelf life. The shelf-life depends largely on storage temperature and also on the type of bacteria associated with the marinated fish (Ucak and Gökoglu, 2016)

The basic principle of cold marinating preservation is associated with the synergic activity of organic acids and salt from marinating bath to the changes in fish flesh (Simat et al., 2011). The incorporation of substances such as organic 
acids (e.g., acetic, lactic and citric acid) and sodium chloride $(\mathrm{NaCl})$ are employed in the seafood marinating process (Topuz 2016).

Weight loss during marinating is main problem of the marinades industry since they primarily affect the cost of fish marinades. Together with acetic acid and water, proteins, lipids, free fatty acids and minerals diffuse into the brine, which decreases the quality and weight yield of the marinades (Topuz, 2016).

"Ready to eat" term is used for products which are prepared by applying appropriate processing techniques and preservation methods; have a certain endurance time; are consumed either directly or by heating to eating temperature; and are consumed alone or by processing with certain substances (Pala and Saygi, 1987; Kanya and Basturk, 2015). Marinated products as well are amongst these products prepared in this manner and presented to the consumers liking. These products, which are obtained by maturation of mainly fish such as anchovies, sardines, and shad fish in vinegar and salt, are consumed in European countries too. These marinades are fish and shellfish products preserved in acetic acid and salt solution to increase the shelf life; they are prepared with additives such as sugar and spices to obtain different flavors, and they are packed in glass jars or plastic containers (Varlık et al., 1993; Kanya and Basturk, 2015).

Synergistic effect of acid and salt content plays the most important role in the marinating process. Selection of suitable procedures for preparing raw fish material for marination, the marinating baths compositions and storage conditions, are carried out in order to achieve a longer shelf life, to maintain quality and achieve good sensory characteristics of marinated products) (Šimat $\boldsymbol{e t}$ al., 2011)

The aim of the work was to compare the quality of the four selected fish product samples (cod in mayonnaise) at the beginning and at the ending of durability by sensory analysis.

\section{MATERIAL AND METHODS}

For exploration, cod salads were used in the experiment and are known as cod in mayonnaise. The sample was purchased in the sales network, three samples were from the Slovak producer and one sample was from the Czech producer. The durability of mayonnaise is 28 days. The salads had approximately the same expiration date. The samples were marked with letters A, B, C and D.

\section{Composition of individual samples}

Sample A - Mayonnaise 40\% (vegetable oil, drinking water, dried egg yolk, mustard, drinking water, mustard, vinegar, sugar, salt, pepper, fermented vinegar, modified starch E 1442, edible salt, stabilizer E 412, E 211, E 202, E 331, sweetener saccharin), cod 35\%, onion, carrot, zucchini, vegetable fiber.

Sample B - Mayonnaise 40\% (vegetable oil, water, fermented vinegar, modified maize starch E 1422, E 1440, dried egg yolk, edible salt, mustard, stabilizer E 412, E 415, sweetener sucralose E 955), cod 35\%, onion (contains $\mathrm{SO}_{2}$ ), carrot, zucchini, vegetable fiber, mustard (water, mustard seed, alcoholic vinegar, sugar, edible salt, spice), chemical preservatives E 211, E 202.

Sample C - $41 \%$ boiled fillet, $41 \%$ mayonnaise (vegetable oil, drinking water, modified maize starch E 1422, thickeners E 412, E 415, E 417), fermented vinegar, sugar, dried egg yolk, acidity regulator E 262, E 331, antioxidants E 301, E 306, preservatives E 200, E 211, marinated onions, sterilized carrots, mustard (drinking water, mustard, fermented vinegar, sugar, edible salt).

Sample D - Mayonnaise 46\% (vegetable oil, drinking water, sugar, fermented vinegar, edible salt, egg yolk, thickeners: guar and xanthan gum, preservatives: sodium benzoate and potassium sorbate), cod meat $36 \%$, marinated onion, sterilized carrot, sterilized cucumbers, mustard (drinking water, mustard seed, fermented vinegar, sugar, edible salt, spices)

\section{Sensory evaluation}

A sensory evaluation was carried out at the Department of Animal Nutrition Evaluation and Processing of Slovak Agricultural University in Nitra, Slovakia The examined samples were selected from the refrigerator for one hour before to the evaluation. The samples was analyzed at the room temperature. The temperature in the sensory lab was $20-21{ }^{\circ} \mathrm{C}$. Samples were served on white porcelain plates according to sensory evaluation requirements. Taste neutralizers were provided for evaluators with white bread and drinking water.

The panel (group) of evaluators consisted of trained evaluators who were informed about levels and method of evaluation. The descriptors focused on the general appearance, color, smell, harmonicity taste, palatability of the product. The taste descriptor was evaluated especially on its, balance of fish-mayonnaise taste, salted, acidity, bitterness and possible foreign flavor. The evaluators assessed the product's fineness and consistency. A form, with twelve descriptors, which were evaluated using a 5 point scale, was developed for the point assessment. Point 5 was defined as the best and Grade 1 as the worst, in all characters besides a descriptor of possible foreign flavor, where a very strong foreign taste was rated as 5 and no foreign taste than 1 . Selected descriptors were chosen based on our judgment, as similar sensory evaluation of mayonnaise has not been found in any professional literature.

We compared each sample with each other and determined whether they differ significantly from each other by evaluating the descriptors. Before the ending of product durability, sensory evaluation was performed again.

Evaluation samples were purchased on the same day as samples from the first evaluation. The analysis procedure was identical to previous evaluations.

\section{Statistical analysis}

Obtained results were carried out according to basic statistical characteristic and ANOVA by the system program SAS 9.3 Enterprise Guide version 4.2. We used the Wilcoxon's t-test for comparison of two independent sets of data.

\section{RESULTS AND DISCUSSION}

The aim of the sensory testing is to describe the product (Szabó, 2014). The most methods using scales consist of measuring the intensity of sensations (Pimente et al., 2016). The sensory evaluation can be divided into an objective sensory assessment and subjective sensory assessment. In objective sensory assessment, personal preferences are minimized by avoiding, as far as possible, bias and feelings of like and dislike. In subjective assessment, a person's natural feelings, such as liking, pleasure, acceptance and value are freely expressed. Since subjective assessments usually involve expressions of pleasure, or degrees of it, they are often called hedonic (FRS, 2018).

Sensory evaluation can be seen as a link between research and development, with a focus made on technical aspects of food, and consumer and marketing research, with a focus on consumers' behavior and psychology (Dijksterhuis, 1995).

The results of sensory evaluation at the beginning of durability are shown in Table 1.

Table 1 Statistical evaluation of sensory parameters at the beginning of durability (mean \pm S.D.)

\begin{tabular}{lcccc}
\hline Parameter & A & sample & C & D \\
\hline General appearance & $4.63 \pm 0.46$ & $4.50 \pm 0,53$ & $4.63 \pm 0,52$ & $4.25 \pm 0,46$ \\
Color & $4.50 \pm 0.53$ & $4.63 \pm 0.52$ & $4.38 \pm 0.52$ & $4.13 \pm 0.35$ \\
Smell & $4.50 \pm 0.53$ & $4.13 \pm 0.35$ & $3.63 \pm 0.52$ & $4.38 \pm 0.52$ \\
Harmonicity taste & $4.63 \pm 0.52$ & $4.50 \pm 0.53$ & $3.50 \pm 0.53$ & $4.38 \pm 0.52$ \\
Palatability & $4.50 \pm 0.53$ & $4.25 \pm 0.46$ & $3.50 \pm 0.53$ & $4.50 \pm 0.53$ \\
Balance of fish-mayonnaise taste & $4.25 \pm 0.46$ & $4.38 \pm 0.52$ & $3.38 \pm 0.52$ & $4.25 \pm 0.46$ \\
Salted & $4.50 \pm 0.53$ & $4.50 \pm 0.53$ & $4.38 \pm 0.52$ & $4.63 \pm 0.52$ \\
Acidity & $4.13 \pm 0.35$ & $4.38 \pm 0.52$ & $3.25 \pm 0.46$ & $4.25 \pm 0.46$ \\
Bitterness & $4.50 \pm 0.53$ & $4.63 \pm 0.52$ & $4.50 \pm 0.53$ & $4.50 \pm 0.53$ \\
Foreign flavor & $1.00 \pm 0.00$ & $1.00 \pm 0.00$ & $1.88 \pm 0.35$ & $1.13 \pm 0.35$ \\
Fineness & $4.50 \pm 0.53$ & $4.63 \pm 0.52$ & $4.00 \pm 0.00$ & $3.25 \pm 0.46$ \\
Consistency & $4.88 \pm 0.35$ & $4.88 \pm 0.35$ & $4.50 \pm 0.53$ & $4.38 \pm 0.52$ \\
\hline Onthe bases &
\end{tabular}

On the bases of the evaluation, product A reached the best average score - 4.50 points for all the parameters evaluated, except the parameter foreign flavor, which reached awarded a 1 point (without foreign flavor). The worst product was C (3.97 points, respectively 1.88 points) and product $\mathrm{D}$ (4.26 points respectively 1.13 points). 


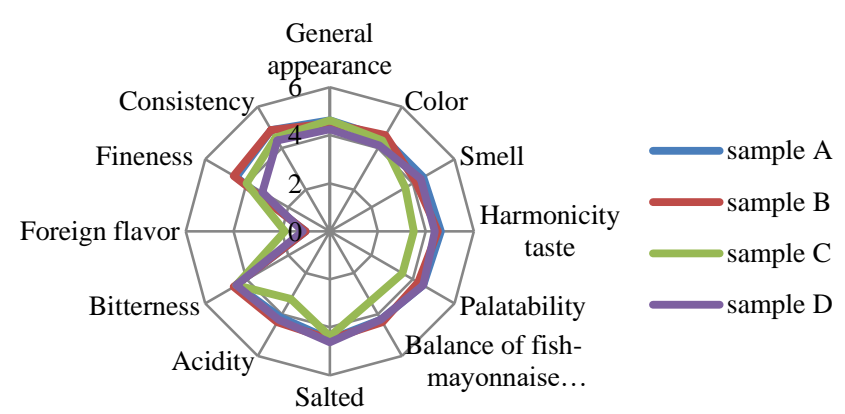

Figure 1 The mutual comparison of sensory parameters at the beginning of durability

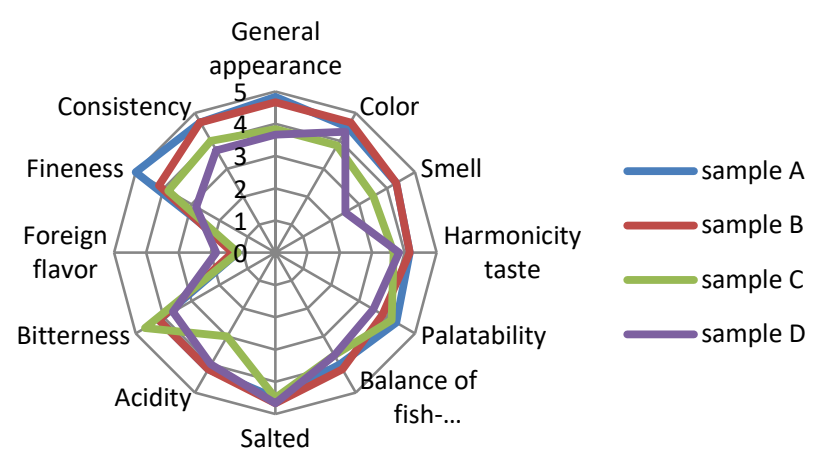

Figure 2 The mutual comparison of sensory parameters at the ending of durability

Table 2 Statistical evaluation of sensory parameters at the ending of durability (mean \pm S.D.)

\begin{tabular}{lcccc}
\hline Parameter & & \multicolumn{2}{c}{ sample } & C \\
& A & B & D \\
\hline General appearance & $4.83 \pm 0,41$ & $4.67 \pm 0,52$ & $3.83 \pm 0,41$ & $3.67 \pm 0,52$ \\
Color & $4.50 \pm 0.55$ & $4.67 \pm 0.52$ & $3.83 \pm 0.41$ & $4.33 \pm 0.52$ \\
Smell & $4.33 \pm 0.52$ & $4.33 \pm 0.52$ & $3.50 \pm 0.55$ & $2.50 \pm 0.55$ \\
Harmonicity taste & $4.12 \pm 0.41$ & $4.17 \pm 0.41$ & $3.67 \pm 0.52$ & $3.83 \pm 0.41$ \\
Palatability & $4.33 \pm 0.52$ & $3.83 \pm 0.41$ & $4.17 \pm 0.41$ & $3.50 \pm 0.55$ \\
Balance of fish-mayonnaise taste & $4.00 \pm 0.00$ & $4.17 \pm 0.41$ & $3.67 \pm 0.52$ & $3.50 \pm 0.55$ \\
Salted & $4.50 \pm 0.55$ & $4.67 \pm 0.52$ & $4.50 \pm 0.55$ & $4.67 \pm 0.52$ \\
Acidity & $4.17 \pm 0.41$ & $4.17 \pm 0.41$ & $3.00 \pm 0.00$ & $4.00 \pm 0.00$ \\
Bitterness & $4.17 \pm 0.41$ & $4.17 \pm 0.41$ & $4.67 \pm 0.52$ & $3.67 \pm 0.52$ \\
Foreign flavor & $1.17 \pm 0.41$ & $1.33 \pm 0.52$ & $1.67 \pm 0.41$ & $1.83 \pm 0.41$ \\
Fineness & $5.00 \pm 0.00$ & $4.17 \pm 0.41$ & $3.83 \pm 0.41$ & $2.83 \pm 0.41$ \\
Consistency & $4.67 \pm 0.52$ & $4.67 \pm 0.52$ & $4.00 \pm 0.00$ & $3.67 \pm 0.52$ \\
\hline
\end{tabular}

At the ending of durability, product A - (4.42 points respectively 1.17 points) was evaluated as the best and product D was evaluated as the worst (3.88 points).

Provable differences were found in the statistical evaluation of the 1 st and 2 nd measurements, on the level of significance $\mathrm{P}<0.05$, especially in product $\mathrm{D}$ in the characteristics of palatability, bitterness, foreign flavor, smell. Product $\mathrm{C}$ revealed provable differences in properties of the general appearance and foreign flavor.

The provable differences in the statistical comparison of individual groups are showed in Table 3.

Provable differences were not founded between the other properties.

Table 3 The statistical comparison between groups at the beginning and at the ending of durability

\begin{tabular}{|c|c|c|c|c|c|c|c|c|c|c|c|c|c|}
\hline group & measurement & GA & $\mathrm{COL}$ & $\mathrm{SM}$ & HT & PA & BA & $\mathrm{SA}$ & $\mathrm{AC}$ & $\mathrm{BI}$ & FF & FI & $\mathrm{CO}$ \\
\hline $\mathrm{A}: \mathrm{B}$ & 1 & & & & & & & & & & & & \\
\hline $\mathrm{A}: \mathrm{B}$ & 2 & & & & & & & & & & & + & \\
\hline $\mathrm{A}: \mathrm{C}$ & 1 & & & + & ++ & + & + & & + & & ++ & + & \\
\hline $\mathrm{A}: \mathrm{C}$ & 2 & + & & & & & & & ++ & & & ++ & + \\
\hline A:D & 1 & & & & & & & & & & & ++ & \\
\hline A:D & 2 & + & & + & & & & & & & & ++ & + \\
\hline $\mathrm{B}: \mathrm{C}$ & 1 & & & & + & + & + & & ++ & & ++ & + & \\
\hline $\mathrm{B}: \mathrm{C}$ & 2 & + & + & & & & & & ++ & & & & + \\
\hline B:D & 1 & & & & & & & & & & & ++ & \\
\hline $\mathrm{B}: \mathrm{D}$ & 2 & + & & + & & & & & & & & + & + \\
\hline C:D & 1 & & + & + & + & + & & & ++ & & + & + & \\
\hline $\mathrm{C}: \mathrm{D}$ & 2 & & & + & & & & & ++ & + & & + & \\
\hline
\end{tabular}

Legend: GA - general appearance, COL - color, SM - smell, HT - harmonicity taste, PA - palatability, BA - balance, SA - salted, AC - acidity,

$\mathrm{BI}$-bitterness, FF - foreign flavour, FI - fineness, $\mathrm{CO}-$ consistency, $+(\mathrm{P}<0.05),++(\mathrm{P}<0.01)$

In assessing the overall appearance of the product, the assessor expresses how the product acts as a whole.

The color of the product is one of its important properties. It is evaluated by the sight, which has the most importance of all senses. On the base of the sight people often decides what to buy (Horčin, 2002). The human visual system detects the light of the wavelengths from about 400 nanometers (violet) to about 700 nanometers (red). The colour mixing is created in the eye, it depends on stimulates of the incoming light (the receptors are stimulates) (Szabó, 2014).

Smell is defined as the property of substances that is perceived by inhalation into the nasal cavity.

Harmonic taste is one of the basic senses that assess the taste properties of substances in the oral cavity. The term harmony of taste means the balance of all components contained in the product.

This sensory depends on our taste buds. Taste buds, located on small bumps on the tongue called fungiform papillae (these are made up of about 50 to 150 taste receptor cells). On the surface of these cells are receptors that bind to small molecules related to flavor. Children have 4000-6000 taste buds, adults 20003000, elderly: 500-1000 (Szabó, 2014).
The palatability of the eatable is the sensation which is perceived in the mouth by inhalation during the bite. It is given by the optimal ratio of all ingredients added in the product.

When assessing the fish-mayonnaise flavor, emphasis is placed on a balanced taste of the raw materials used mainly in our case after marinated fish meat, vinegar, vegetables and seasoning.

Salty taste is among the five basic tastes. The feeling of saltiness is caused by a stone salt, it means sodium chloride.

The eatable acidity is related to the amount of acids present. In particular, nondissociated forms of organic acids, citric acid and malic acid are particularly important. Often, however, other acids also occur in eatables, e.g. ascorbic, tartaric, lactic and acetic.

Bitterness is caused various bitter chemical compounds of organic and inorganic nature. They occur during processing and storage of foodstuffs by chemica reactions or by the activities of their own enzyme systems.

The foreign flavor is characterized as an undesirable flavor that is caused by the decomposition processes of some eatable ingredients or a component that is artificially added. 
Fineness is a geometric textural characteristic related to the structure of the eatable, namely its shape and particle size. The eatable consistency is evaluated by tactile sensation, without put it in mouth. It is measured with fingers. Perception of aroma, taste, and texture in foods is a dynamic, not a static phenomenon. Typically classical sensory evaluation quantifies the sensory response using a unipoint measurement. Judges must time-average or integrate their responses to provide single intensity values (Lee and Pangborn, 1986; Cliff and Heymann, 1993).

A sensory assessment of fish salads packed in a modified atmosphere (gaspackaged) was followed by Metin et al. (2002) who found statistically significant differences between the samples that were packed under atmospheric conditions.

\section{CONCLUSION}

The cod in mayonnaise is a popular product among consumers, placing emphasis on the general appearance, color and especially the typical fish taste of cod and its balance with other raw materials used in its manufacture. The product exhibits characteristic sensory properties during its use. The approaching ending of the durability date occurs gradual an overlap of fish taste, such as an acetic taste, as reflected assessors' evaluation. Assessors put emphasis on balance of taste.

\section{REFERENCES}

(G. Borgstrom ed.) Part 1, p. 221, Academic Press, New York (G. Borgstrom ed.) Part 1, p. 221, Academic Press, New York (G. Borgstrom ed.) Part 1, p. 221, Academic Press, New York.

Ackman, R. G. 1988. Nutritional composition of fats in seafoods. Progress in Food \& Nutrition Science, 13, 3-4, 161-289.

Albert, C. M., Hennekens, C. H., O'Donnell, C. J., Ajani, U. A., Carey, V J., Willett, W. C., Ruskin, J. N., Manson, J. E. 1998. Fish Consumption and Risk

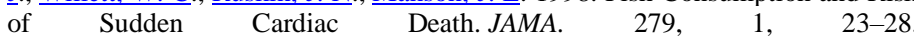
https://doi.org/10.1001/jama.279.1.23

Baltic, M. Z., Boskovic, M. 2015. When man met meat: meat in human nutrition from ancient times till today. Meat Safety and Quality: Where it goes? International 58th Meat Industry Conference,Elsevier Serbia. Procedia Food Science 5, 6 - 9 https://doi.org/10.1016/j.profoo.2015.09.002

Beardsworth, A. and Keil, T. 1997. Sociology on the menu. An invitation to the study of food and society. London: Routledge. 278 p. ISBN 0-415-11424-1

Bekker, G. A., Tobi, H., Fischer, A. R.H. 2017. Meet meat: An explorative study on meat and cultured meat as seen by Chinese, Ethiopians and Dutch. Appetite 114, 82-92. https://doi.org/10.1016/j.appet.2017.03.009

Berkel, B. M., Boogaard, B., Heijnen, C. 2004. Preservation of fish and meat [online]. Wageningen: Digigrafi 86 p. ISBN: 90-72746-01-9.

Bohrer, B.M. 2017. Review: Nutrient density and nutritional value of meat products and non-meat foods high in protein. Trends in Food Science \& Technology, 65, 103-112. https://doi.org/10.1016/j.tifs.2017.04.016

Boland, M. J., Rae, A. N., Vereijken, J. M., Meuwissen, M. P. M., Fischer, A. R. H., van Boekel, M., Hendriks, W. H. 2013. The future supply of animal-derived protein for human consumption. Trends in Food Science \& Technology, 29, 1, 62 73. Journal Article https://doi.org/10.1016/j.tifs.2012.07.002

Chrysohoou, C., Panagiotakos, D. B., Pitsavos, C., Skoumas, J., Krinos, X., Chloptsios, Y., Nikolaou, V., Stefanadis, C. 2007. Long-term fish consumption is associated with protection against arrhythmia in healthy persons in a Mediterranean region - The ATTICA study. American Journal of Clinical Nutrition, 85, 5, 1385-1391. https://doi.org/10.1093/ajen/85.5.1385

Cliff, M. and Heymann, H. 1993. Development and use of time-intensity methodology for sensory evaluation: A review. Food Research International. 26, 5, 375-385. https://doi.org/10.1016/0963-9969(93)90081-s

De Deckere, E.A.M. 1999. Possible beneficial effect of fish and fish n-3 polyunsaturated fatty acids in breast and colorectal cancer. Eur. J. Cancer Prev. 8, 3, 213-221. https://doi.org/10.1097/00008469-199906000-00009

Dijksterhuis, G. 1995. Multivariate data analysis in sensory and consumer science: An overview of developments, Trends in Food Science \& Technology, 6 , 6, 206-211. ISSN 0924-2244. https://doi.org/10.1016/s0924-2244(00)89056-1

FAO, 2018. Fish and human nutrition http://www.fao.org/fileadmin/user_upload/newsroom/docs/BlueGrowthNutrition Rev2.pdf

FRS, 2018. Sensory Assessment of Fish and Shellfish Quality. Fisheries research services.

http://www.gov.scot/uploads/documents/ae13taste.pdf.

Horčin, V. 2002. Senzorické hodnotenie potravín. Nitra : SPU, 139 p. ISBN 808069-112-6.

Ucak and Gökoglu, 2016. Effect of high hydrostatic pressure on sensory quality of marinated herring (Clupeaharengus). Journal of Food Processing and Preservation, 41, 2, p.12784. ISSN 1745-4549 https://doi.org/10.1111/ifpp.12784 Kaushik, M., Mozaffarian, D., Spiegelman, D., Manson, J. E., Willett, W. C., Hu, F. B. 2009. Long-chain omega-3 fatty acids, fish intake, and the risk of type 2 diabetes mellitus. The American Journal of Clinical Nutrition, 90, 3, 613-620. https://doi.org/10.3945/ajen.2008.27424
Kaya, G. K., Baştürk, Ö. 2015. Determination of some quality properties of marinated sea bream (Sparus Aurata L., 1758) during cold storage. Food Sci. Technol (Campinas), 35, 2, 347-353. ISSN 1678-457X https://doi.org/10.1590/1678-457x.6619

Kris-Etherton, P. M., Harris, W. S., Appel, L. J. 2002. Fish consumption, fish oil, omega-3 fatty acids, and cardiovascular disease. Circulation, 106, 2747-2757. https://doi.org/10.1161/01.cir.0000038493.65177.94

Lee, W. E. III and Pangborn, R. M. 1986. Time-intensity: the temporal aspects of sensory perception. Food Technol., 40, 71-8, 82.

Lund E. 2018. Fish and cancer Lund E. Nutrition and lifestyle: opportunities for cancer prevention Chapter 4 Meat, fish and dairy products 187-189

Mensink R.P., Zock P.L., Kester A.D., Katan M.B. 2003. Effects of dietary fatty acids and carbohydrates on the ratio of serum total to HDL cholesterol and on serum lipids and apolipoproteins: a meta-analysis of 60 controlled trials. Am J Clin Nutr, 77, 5, 1146-1155. https://doi.org/10.1093/ajen/77.5.1146

Metin, S., Erkan, N., Baygar, T., Ozden, O. 2002. Modified atmosphere packaging of fish salad. Fisheries science, 68, 1, 204-209. https://doi.org/10.1046/j.1444-2906.2002.00409.x

Meyer, V. 1965. Marinades. Fish as Food. Academic Press, New York. 3. 1, 165 193. doi.org/10.1016/b978-0-12-395571-5.50013-2

MEYER, V. 1965. Marinades. In Fish as Food, Vol. 3

MEYER, V. 1965. Marinades. In Fish as Food, Vol. 3

MEYER, V. 1965. Marinades. In Fish as Food, Vol. 3

Morales, L. E. and Higuchi, A. 2018. Is fish worth more than meat? - How consumers' beliefs about health and nutrition affect their willingness to pay more for fish than meat. Food Quality and Preference. 65, 101-109. https://doi.org/10.1016/j.foodqual.2017.11.004

Mozaffarian, D. 2005. Effects of dietary fats versus carbohydrates on coronary heart disease: A review of the evidence. Current Atherosclerosis Reports, 7, 6 , 435-445. https://doi.org/10.1007/s11883-005-0060-y

Mozaffarian, D. and Wu, J.H. 2011. Omega-3 fatty acids and cardiovascular disease: effects on risk factors, molecular pathways, and clinical events. $\mathrm{J} \mathrm{Am}$ Coll Cardiol,;58, 20, 2047-2067. https://doi.org/10.1016/j.jacc.2011.06.063

Mozaffarian, D., Rimm, E. B. 2006. Fish intake, contaminants, and human health - Evaluating the risks and the benefits. Journal of the American Medical Association, 296, 1885-1899. https://doi.org/10.1001/jama.296.15.1885

Pala, M. and Sayg1, Y. B. 1987. Catering Uygulamaları: Risk ve Gelecek Perspektif. Glda Dergisi, 12, 3-11.

Pieniank, Z., Verbeke, W., Scholderer, J. 2010. Health-related beliefs and consumer knowledge as determinants of fish consumption. Journal of Human Nutrition and Dietetics, 23, 480-488 https://doi.org/10.1111/j.1365277x.2010.01045.x

Pimentel T.C., da Cruz, G. A., Deliza R. 2016. Sensory Evaluation: Sensory Rating and Scoring Methods. In: Caballero, B., Finglas, P., Toldrá, F. (eds.) The Encyclopedia of Food and Health. Oxford: Academic Press. 4, 744- 749.

SAS. 2008. 9.3 Enhanced Logging Facilities, Cary, NC: SAS Institute Inc. 2008.

Šimat, V., Bogdanović, T., Bulić, M. 2011. The effect of different marinating baths on sensory properties and shelf life parameters of cold marinated anchovies (Engraulis encrasicolus, L.). Meso. 8, 2, 80-88.

Simopoulos, A. P. 1999. Essential fatty acids in health and chronic disease. Am J Clin Nutr. 70, 3, 560-569. https://doi.org/10.1093/ajcn/70.3.560s

Sioen, I., Matthys, C. De, Backer, G., Van Camp, J., De Henauw, S. 2007 Importance of seafood as nutrient source in the diet of Belgian adolescents. Journal of Human Nutrition and Dietetics, 20, 580-589. https://doi.org/10.1111/j.1365-277x.2007.00814.x

Szabó P. B., 2014. Sensory evaluation in food industry. In: TÁMOP-4.1.1.C12/1/KONV-2012-0014 „Élelmiszerbiztonság és gasztronómia vonatkozású egyetemi együttmüködés, DE-SZTE-EKF-NYME „, projekt segítségével jött létre, 32.

Tanskanen, A., Hibbeln, J. R., Tuomilehto, J., Uutela, A., Haukkala, A., Viinamäki, H., Lehtonen, J., Vartiainen, E. 2001. Fish consumption and depressive symptoms in the general population in Finland. Psychiatric Services, 52, 529-531 https://doi.org/10.1176/appi.ps.52.4.529

Topuz, O. K. 2016. Effects of Marinating Time, Acetic Acid and Salt Concentrations on the Quality of Little Tunny Fish (Euthynnus alletteratus) Fillet. Journal of Food Processing and Preservation, 40, 6, 1154-1163. https://doi.org/10.1111/jfpp.12696

Uc,ak, I. and Gokog`lu, N. (2014). Effects of High Pressure Processing on the Sensory Properties of Fish Marinade. Journal of Food Processing and Preservation, 41, 1-5.

Varlik, C., Uğur, M., Gökoğlu, N., Gün, H. 1993. Principles and methods of quality control in seafood. İstanbul: Food Technology Association

Wallin, A., Di Giuseppe, D., Orsini, N., Patel, P. S., Forouhi, N. G., Wolk, A. 2012. Fish consumption, dietary long-chain n-3 fatty acids, and risk of type 2 diabetes: systematic review and meta-analysis of prospective studies. Diabetes Care. 35, 4, 918-929. https://doi.org/10.2337/dc11-1631

Willett, W. C. 2012. Dietary fats and coronary heart disease. J Intern Med, 272, 1, 13-24. https://doi.org/10.1111/j.1365-2796.2012.02553.x 
Wood, J. D. 2017. Chapter 20 - Meat Composition and Nutritional Value, In Lawrie's Meat Science, A volume in Woodhead Publishing Series in Food Science, Technology and Nutrition 2017, 635-659, Elsevier, Eight Edition, 730 p. ISBN 978-0-08-100694-8 https://doi.org/10.1016/b978-0-08-100694-8.00020-

Zhang, Y., Chen, J., Qiu, J., Li, Y., Wang, J., Jiao, J. 2016. Intakes of fish and polyunsaturated fatty acids and mild-to-severe cognitive impairment risks: a doseeresponse meta-analysis of 21 cohort studies. Am J Clin Nutr, 103, 2, 330340. https://doi.org/10.3945/ajcn.115.124081

SIMAT, V., BOGDANOVIC, T. and BULIC, M. 2011. The effect of different marinating baths on sensory properties and shelf life parameters of cold marinated anchovies (Engraulis encrasicolus, L.). MESO 12, 81-88. LKNUR $\mathrm{UC}, \mathrm{AK}$ an 